\title{
PERAN BELANJA MODAL PEMERINTAH DAN INVESTASI PEMBANGUNAN MANUSIA DALAM MENGURANGI TINGKAT KEMISKINAN DI INDONESIA
}

\author{
Khodijah Mustaqimah $^{1}$, Sri Hartoyo ${ }^{2}$, Idqan Fahmi \\ ${ }^{1}$ Mahasiswa Program Magister Ilmu Ekonomi, FEM IPB \\ ${ }^{2}$ Staff Pengajar FEM IPB
}

\begin{abstract}
Poverty is a measure of socio-economic conditions in assessing the success of development undertaken by a government in a region. There are many negative impacts resulted from poverty, among others, social and economic problems. People who live in poverty usually suffer from malnutrition, poor health, high illiteracy rates, are in poor environment and in lack of access to infrastructure and adequate public services. The purpose of this study was to analyze the impact of human development and government capital expenditure on reducing poverty in Indonesia. The model was estimated by using 2SLS method. Several simulations was also conducted to look at the impact of the allocations of government expenditure on health, education and government capital expenditure on reducing poverty. The results showed that government capital expenditure and human development have significant impacts on reducing poverty in Indonesia with government expenditure on education gives the greatest impact.
\end{abstract}

Keywords: Capital, Expenditure, Government, Human Development, Poverty

\section{PENDAHULUAN}

Kemiskinan merupakan salah satu tolak ukur kondisi sosial ekonomi dalam menilai keberhasilan pembangunan yang dilakukan pemerintah di suatu daerah. Banyak dampak negatif yang dihasilkan dari kemiskinan, antara lain menimbulkan masalah sosial dan ekonomi (Saputra 2011). Badan Pusat Statistik (BPS) mengukur kemiskinan dengan menggunakan konsep kemampuan memenuhi kebutuhan dasar (basic needs approach). Dengan pendekatan ini, kemiskinan dipandang sebagai ketidakmampuan dari sisi ekonomi untuk memenuhi kebutuhan dasar makanan dan bukan makanan yang diukur dari sisi pengeluaran.

Angka kemiskinan yang cenderung menurun secara melambat menunjukkan bahwa strategi pe- nanggulangan yang dilakukan oleh pemerintah belum optimal. Hal ini tergambar dari belum meratanya pembangunan antar daerah di Indonesia. Secara umum, persentase penduduk miskin menunjukkan tren menurun secara melambat selama periode 20102013. Tingkat penurunan kemiskinan yang hanya mencapai $1,6 \%$ pada tahun 2013 adalah yang terkecil sepanjang periode penelitian empat tahun terakhir.

Dimana pada tahun 2010 pemerintah berhasil menurunkan tingkat kemiskinan dari $13,33 \%$ menjadi $12,36 \%$ atau turun sebesar 7,27\%. Selain itu angka kemiskinan di Indonesia pada periode penelitian juga masih tergolong tinggi, yakni pada tahun 2013, penduduk miskin di Indonesia berjumlah 28,55 juta jiwa. Salah satu penyebab tingginya kemiskinan adalah rendahnya kualitas SDM (Sulistyowati, 2011). Tingkat ke- 
miskinan dapat bersumber dari rendahnya tingkat pendidikan pekerja. Tingkat pendidikan yang rendah menyebabkan produktivitas tenaga kerja rendah dan mempengaruhi tingkat pendapatannya. Rendahnya tingkat pendapatan menyebabkan masyarakat miskin tidak dapat memenuhi kebutuhan dasarnya dengan baik sehingga mempengaruhi tingkat pendidikan dan kesehatannya, demikian seterusnya berputar tanpa ada ujung pangkalnya (the vicious cycle of poverty).

Salah satu penyebab kemiskinan adalah karena rendahnya derajat kesehatan. Taraf kesehatan dan gizi yang rendah menyebabkan rendahnya daya tahan fisik, daya pikir dan prakarsa. Menurut Sumarsono (2009) Investasi SDM sangat menentukan dalam mendorong laju pertumbuhan ekonomi riil, bahkan krisis ekonomi memberi pengalaman bahwa negara yang mempunyai SDM yang baik akan lebih cepat keluar dari krisis ekonomi. Investasi sumber daya manusia yakni di bidang kesehatan dan pendidikan. Hal tersebutlah yang mendasari betapa pentingnya pembangunan manusia.

Negara dengan tingkat pendapatan per kapita yang tinggi secara umum akan lebih mampu meningkatkan kualitas modal manusianya dibandingkan negara-negara miskin. Namun buktibukti yang ada menunjukkan bahwa meskipun suatu negara mampu meningkatkan pendapatan per kapita tanpa harus memperbaiki kualitas pendidikan dan kesehatan secara signifikan, tidak dapat dipastikan bahwa peningkatan pendapatan per kapita tersebut akan diinvestasikan ke dalam pendidikan dan kesehatan anak-anak secara memadai (Todaro dan Smith, 2003).

Karena hubungan yang demikian, pasar tidak dapat diandalkan sepenuhnya untuk memberikan level pendidikan dan kesehatan yang efisien secara sosial. Itulah sebabnya, dibutuhkan juga investasi pemerintah pada sektor pendidikan maupun sektor kesehatan untuk dapat menghasilkan sumber daya manusia yang berkualitas, yang merupakan dasar bagi pertumbuhan ekonomi dalam jangka panjang (Sumargo dan Yuniarty, 2009).

Beberapa hasil penelitian menunjukkan bahwa pengeluaran di sektor publik sangat bermanfaat untuk meningkatkan pembangunan manusia dan mengurangi penduduk miskin, seperti penelitian yang telah dilakukan oleh antara lain Fan dan War (2000), Gomanee dan Karuna (2003), Brata (2005) dan Chemingui (2007). Menurut Blankeanu dan Simpson (2004), pengeluaran pemerintah untuk pendidikan dan kesehatan berpengaruh langsung dalam meningkatkan human capital dan mendorong terjadinya pertumbuhan ekonomi dalam jangka panjang.

Menurut Yudhoyono (2004), kebijakan fiskal merupakan instrumen utama untuk mengatur bagaimana pendapatan negara dialokasikan kepada aktivitas ekonomi masyarakat secara adil dan digunakan untuk kemakmuran rakyat. Belanja modal pemerintah berperan penting dalam mengurangi kemiskinan di Indonesia.

Beberapa studi tidak secara khusus mengkaji pengaruh investasi kapital melalui belanja modal pemerintah, dan pengaruh investasi pembangunan manusia yang direpresentasikan oleh pengeluaran pemerintah ]pada sector pendidikan dan kesehatan terhadap pengurangan kemiskinan di Indonesia. Penelitian ini sangat penting untuk dilakukan karena menyangkut kesejahteraan masyarakat, dan pengurangan kemiskinan itu sendiri. Melihat betapa petingnya kebijakan fiskal pemerintah dan pembangunan 
manusia dalam mengurangi kemiskinan di Indonesia, maka penelitian ini dilakukan untuk melihat pengaruh belanja modal pemerintah dan pembangunan manusia dalam mengurangi kemiskinan, serta implikasinya terhadap kebijakan pemerintah dalam upaya pengurangan kemiskinan di Indonesia.

Berdasarkan uraian diatas maka tujuan penelitian adalah (1) Menganalisis peran belanja modal pemerintah dan investasi pembangunan manusia dalam mengurangi tingkat kemiskinan di Indonesia.

Menganalisis implikasi kebijakan pemerintah dalam upaya pengurangan kemiskinan di Indonesia.

\section{TINJAUAN PUSTAKA}

\section{Kemiskinan}

Secara umum, kemiskinan dapat dibedakan ke dalam dua jenis yaitu kemiskinan absolut dan kemiskinan relatif. Kemiskinan absolut adalah suatu keadaan dimana kebutuhan minimum utuk bertahan hidup tidak dapat dipenuhi dengan pendapatan yang dimiliki seseorang atau suatu keluarga. Artiya, ketika tingkat pendapatan tidak dapat memenuhi kebutuhan dasar minimum, maka hal tersebut dapat dikatakan miskin. Hal ini berarti diperlukan suatu tingkat pendapatan minimum yang memungkinkan seseorang atau suatu keluarga itu dapat memenuhi kebutuhan dasar minimum-nya.

\section{Pembangunan Manusia}

Menurut Human Development Report (HDR) pembangunan manusia adalah suatu proses untuk memperbanyak pilihan yang dimiliki manusia. Pilihan yang terpenting adalah untuk berumur panjang dan sehat, memiliki ilmu pengetahuan dan akses terhadap sumber daya yang dibutuhkan untuk hidup secara layak. Investasi dibidang sumber daya manusia adalah pengorbanan sejumlah dana yang dikeluarkan dan memiliki kesempatan memperoleh penghasilan selama proses investasi (Sumarsono, 2009). Modal manusia merupakan salah satu faktor penting dalam pembangunan ekonomi. Dengan modal manusia yang berkualitas, kinerja ekonomi diyakini juga akan lebih baik.

Menurut Todaro dan Smith (2003), investasi pendidikan dan kesehatan menyatu dalam pendekatan modal manusia. Modal manusia adalah istilah yang sering digunakan untuk pendidikan, kesehatan dan kapasitas manusia yang dapat meningkatkan produktivitas jika hal ini ditingkatkan. Kesehatan merupakan inti dari kesejahteraan dan pendidikan adalah hal pokok untuk mencapai kehidupan yang lebih layak. Keduanya adalah hal yang fundamental untuk membentuk kapabilitas manusia yang lebih luas, dan menjadi faktor penting dalam pem-bangunan ekonomi.

Besarnya pengeluaran pemerintah menjadi ukuran seberapa besar perhatian pemerintah pada usaha pengembanan kualitas sumber daya manusia. Perbaikan kualitas SDM juga tergantung pada tersedianya infrastruktur untuk menunjang investasi sumber daya manusia.

Pencapaian kualitas pembangunan manusia sangat ditentukan oleh kemampuan keuangan daerah]. Peningkatan kualitas SDM akan meningkatkan produktivitas tenaga kerja, yang kemudian dapat menjadi penggerak bagi pertumbuhan ekonomi, dan pengurangan kemiskinan itu sendiri (Sulistyowati, 2011).

\section{Belanja Modal Pemerintah}

Belanja modal (pembangunan) adalah pengeluaran yang ditujukan untuk 
kepentingan publik dalam rangka meningkatkan kemampuan masyarakat dan menumbuhkan perekonomian daerah. Belanja pemerintah diprioritaskan untuk melindungi dan meningkatkan kualitas kehidupan masyarakat dalam upaya memenuhi kewajiban daerah yang diwujudkan dalam bentuk peningkatan pelayanan dasar, pendidikan, penyediaan fasilitas pelayanan kesehatan, fasilitas sosial dan fasilitas umum yang layak serta mengembangkan jaminan sosial (UU 32/2004). Peranan pengeluaran pemerintah (G) di negara berkembang sangat signifikan mengingat kemampuan sektor swasta untuk mendorong pertumbuhan ekonomi masih sangat terbatas, oleh karena itu peranan pemerintah sangatlah penting.

\section{Distribusi Pendapatan dan Per- tumbuhan Ekonomi}

Produk Domestik Regional Bruto (PDRB) per kapita merupakan salah satu indikator untuk melihat keberhasilan pembangunan dan merupakan syarat bagi pengurangan tingkat kemiskinan. Hasil PDRB yang menyebar di setiap golongan masyarakat termasuk di golongan penduduk miskin merupakan syarat bagi pengurangan penduduk miskin.

PDRB dan tingkat kemiskinan memiliki hubungan yang bersifat negatif. Produk Domestik Regional Bruto yang meningkat akan mengurangi tingkat kemiskinan sehingga percepatan peningkatan PDRB penting untuk menurunkan tingkat kemiskinan. Menurut Todaro dan Smith (2003), hubungan pertumbuhan ekonomi dengan ketimpangan pendapatan yang diteliti oleh Simon Kuznets menjelaskan bahwa pada tahap awal pertumbuhan ekonomi, distribusi pendapatan cenderung memburuk, namun pada tahap selanjutnya, distribusi pendapatan akan membaik. Beberapa kasus seperti Taiwan, Korea Selatan, China, dan Sri Lanka menunjukkan bahwa peningkatan pendapatan nasional dapat disertai dengan penurunan ketimpangan pendapatan. Hal ini tergantung pada karakter proses pembangunan yang dijalankan oleh masing-masing negara. Di berbagai negara berkembang tidak terdapat hubungan yang kuat antara tingkat pendapatan perkapita dengan tingkat ketimpangan distribusi pendapatan.

Kondisi yang ada menunjukkan bahwa pertumbuhan ekonomi tidak selalu diikuti oleh pemerataan hasil-hasil pembangunan. Masalah pemerataan memerlukan perincian tentang distribusi apa yang telah dihasilkan dari pembangunan tersebut, serta kelompok masyarakat mana yang menikmatinya. Hubungan antara pendapatan dan pemerataan masih menjadi kontroversi.

Pemerataan pendapatan hanya dapat dicapai jika laju pertumbuhan ekonomi diturunkan, sebaliknya pertumbuhan ekonomi yang tinggi akan disertai kemerosotan dalam pembagian pendapatan atau kenaikan dalam ketimpangan (trade off). Selain itu Nanga (2006) menjelaskan bahwa tidak ada hubungan yang jelas antara pertumbuhan pendapatan perkapita dengan perubahan proporsi pendapatan.

\section{Penelitian Terdahulu}

Hudaya (2009), Wiguna (2013), Putri dan Yuliarmi (2013), Dagdeviren et al. (2002), Bidani dan Ravallion (1993), Fane dan War (2002), Balisacan et al. (2003) melakukan penelitian mengenai faktor-faktor yang mempengaruhi tingkat kemiskinan di Indonesia dengan menggunakan analisis data panel.

Variabel yang digunakan pada penelitian Hudaya (2009) adalah Tingkat Pengangguran Terbuka (TPT), 
Pendapatan Perkapita (PP), dan Angka Melek Huruf (AMH). Hasil penelitian ini menunjukkan bahwa variabel TPT, $\mathrm{PP}$, dan AMH memiliki pengaruh yang signifikan terhadap tingkat kemiskinan di Indonesia. Tingkat Pengangguran Terbuka (TPT) memiliki korelasi yang positif dengan tingkat kemiskinan, sedangkan Pendapatan Perkapita (PP), dan Angka Melek Huruf (AMH) memiliki korelasi yang negatif terhadap tingkat kemiskinan.

Variabel yang digunakan dalam penelitian Wiguna (2013) PDRB, Pendidikan, dan Pengangguran. Hasil penelitian Wiguna (2013) menunjukkan bahwa variabel PDRB berpengaruh negatif dan signifikan terhadap kemiskinan di Jawa Tengah, tingkat pendidikan berpengaruh negatif dan signifikan terhadap kemiskinan di Jawa Tengah, tingkat pengangguran berpengaruh positif dan signifikan terhadap kemiskinan di Jawa Tengah.

Selain itu variabel yang digunakan dalam penelitian Putri dan Yuliarmi (2013) adalah pertumbuhan ekonomi, pendidikan (rata-rata lama sekolah), dan Tingkat Pengangguran Terbuka (TPT). Hasil penelitian tersebut menunjukkan bahwa variabel pertumbuhan ekonomi, UMK, dan pendidikan (rata-rata lama sekolah) memiliki pengaruh yang negatif terhadap tingkat kemiskinan, sedangkan variabel Tingkat Pengangguran Terbuka (TPT) tidak memiliki pengaruh yang signifikan terhadap tingkat kemiskinan di Provinsi Bali pada tahun 2007-2011.

Penelitian Fane dan War (2002) menelaah bagaimana pertumbuhan ekonomi dapat mengurangi kemiskinan di Indonesia. Hasil studi menyimpulkan bahwa semakin besar pertumbuhan meningkatkan returns pendapatan khususnya bagi kaum miskin daripada yang bukan penduduk miskin, maka semakin besar kemungkinan untuk menurunkan kemiskinan dan ketimpangan pendapatan. Pertumbuhan mempengaruhi kemiskinan dan ketimpangan pendapatan secara berbeda, karena kaum miskin dan non miskin memiliki faktor pendapatan di dalam proporsi yang berbeda.

Hasil penelitian Balisacan et al (2003) menyatakan bahwa kesejahteraan penduduk miskin yang diukur dari kaum miskin dipengaruhi oleh pertumbuhan ekonomi,selain itu modal manusia (yang diukur dengan rata-rata lama sekolah), terms of trade, infrastruktur dan akses terhadap teknologi juga berpengaruh nyata terhadap kesejahteraan penduduk miskin.

Penelitian yang dilakukan oleh Sumargo dan Yuniarty (2009), Sulistyowati (2011) membahas mengenai peran pengeluaran pemerintah terhadap pembangunan manusia, dengan menggunakan metode analisis persamaan simultan. Penelitian Sumargo dan Yuniarty (2009) menunjukkan bahwa investasi sektor pendidikan berpengaruh signifikan dan paling besar dalam meningkatkan pencapaian pembangunan manusia.

Sedangkan hasil penelitian Sulistyowati (2011) menunjukkan bahwa pengeluaran pemerintah untuk sector pendidikan dan kesehatan belum efektif dalam meningkatkan kedua sektor tersebut. Dalam jangka panjang, kesehatan berpengaruh positif dan elastis dalam meningkatkan pendidikan di Jawa Tengah.

Penelitian yang dilakukan oleh Sang Jung dan Thorbecke (2001), Eigbiremolen dan Anaduaka (2014), Widodo et al (2011), Nurmainah (2013 membahas mengenai peran belanja pemerintah dan indeks pembangunan manusia dalam mengurangi tingkat kemiskinan dengan menggunakan analisis data panel, CGE model, dan analisis cross section. 
Variabel yang digunakan pada penelitian Widodo et al (2011) adalah belanja publik pada pendidikan dan kesehatan,serta indeks pembangunan manusia. Hasil penelitian ini menunjukkan bahwa variabel belanja publik dan indeks pembangunan manusia memiliki pengaruh negatif terhadap tingkat kemiskinan di Jawa Tengah.

Tingkat pendidikan dan belanja pembangunan memberikan pengaruh negatif terhadap kemiskinan pada kabupaten/kota di Provinsi Bali. Demikian juga dengan belanja modal, tenaga kerja terserap, dan indeks pembangunan manusia berpengaruh negatif terhadap kemiskinan di Provinsi Jawa Tengah.

Selain itu Sang Jung dan Thorbecke (2001) melakukan penelitian yang menggunakan CGE model. Hasil dari penelitian ini menunjukkan bahwa pengeluaran public pada kesehatan dapat meningkatkan pertumbuhan ekonomi, dan efektif dalam mengurangi kemiskinan. Pengeluaran pemerintah pada pendidikan dan kesehatan meningkatkan kualitas pendidikan, dan menurunkan tingkat kematian.

Eigbiremolen dan Anaduaka (2014) melakukan penelitian dengan menggunakan analisis augmented Solow human capital-growth model. Hasil dari penelitian ini menunjukkan bahwa terdapat peningkatan peforma ekonomi setiap peningkatan pada pembangunan manusia. Sehingga para pembuat kebijakan harus lebih berfokus dan meningkatkan upaya dalam pembangunan manusia.

Perbedaan penelitian ini dengan penelitian sebelumnya terletak pada variabel yang mempengaruhi kemiskinan yaitu belanja modal pemerintah dan pembangunan manusia dengan menganalisis 29 provinsi di
Indonesia pada tahun 2010 sampai 2013.

\section{METODE PENELITIAN}

\section{Jenis dan Sumber Data}

Jenis data yang digunakan pada penelitian ini adalah data sekunder yang berupa gabungan data time series dan cross section. Data deret waktu meliputi data tahunan dari tahun 2010 sampai dengan tahun 2013, sedangkan data cross section meliputi 29 provinsi di Indonesia. Sumber data pada penelitian ini berasal Badan Pusat Statistik Indonesia. Peneliti juga menggunakan sumber-sumber lain seperti jurnal, artikel serta literaturliteratur lainnya untuk menambah informasi terkait penelitian.

\section{Metode Analisis Data}

Data yang digunakan dalam penelitian ini adalah data sekunder yang berupa gabungan data time series dan cross section. Data deret waktu meliputi data tahunan dari tahun 2010 sampai dengan tahun 2013, sedangkan data cross section meliputi 29 provinsi di Indonesia. Sumber data pada penelitian ini berasal Badan Pusat Statistik Indonesia. Model yang digunakan dalam menganalisis adalah sistem persamaan simultan. Kerangka pemikiran pada penelitian ini adalah sebagai berikut: 


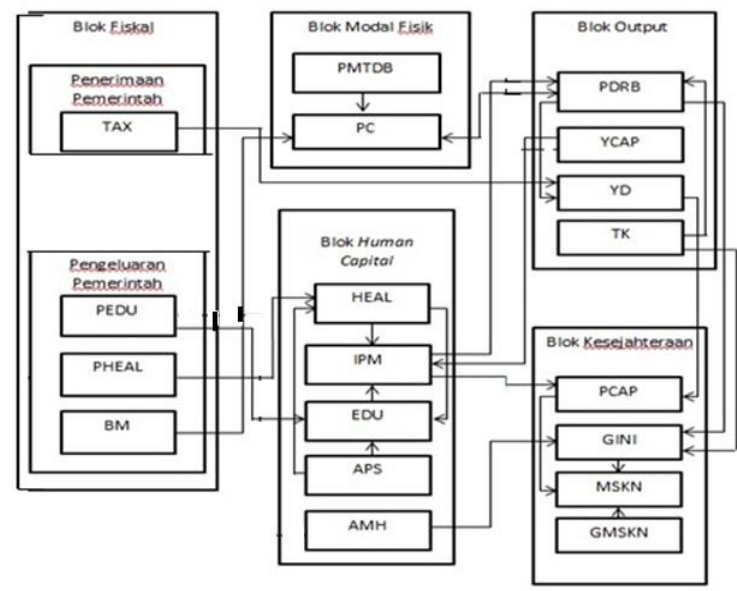

Gambar 1 Kerangka Pemikiran

\section{Model Penelitian}

\section{- Blok Modal Manusia}

-Kesehatan :

HEAL $_{i t}=\mathrm{a}_{0}+\mathrm{a}_{1} \mathrm{PHEAL}_{\mathrm{Pt}}+$ a2HEALit-1+ a3APSit + Uit

Diharapkan bahwa a1, a2, a3 >0

-Pendidikan :

EDUit $=b_{0}+b_{1}$ PEDU it + b2APSit + b3HEALit +Uit

Diharapkan bahwa b1, b2, b3 >0

-Indeks Pembangunan Manusia

$$
\begin{aligned}
& \text { IPMit }=\mathrm{c}_{0}+\mathrm{c} 1 \mathrm{HEALit}+ \\
& \mathrm{c}_{2} \mathrm{EDU}_{\mathrm{it}}+\mathrm{c} 3 \text { YCAP }_{\mathrm{it}}+\mathrm{U}_{\mathrm{it}}
\end{aligned}
$$

Diharapkan bahwa c1, c2, c3 >0

\section{- Blok Modal Fisik}

- Physical Capital

$$
\begin{aligned}
& \mathrm{PC}_{i t}=\mathrm{d}_{0}+\mathrm{d}_{1} \mathrm{PMTDB}_{i t}+ \\
& \mathrm{d}_{2} \mathrm{BM}_{i t}+\mathrm{d}_{3} \mathrm{PDRB}_{\mathrm{it}}+\mathrm{U}_{\mathrm{it}}
\end{aligned}
$$

Diharapkan bahwa d1, d2, d3 >0

\section{- Blok Output}

- Produk Domestik Regional Bruto

$\mathrm{PDRB}_{i t}=\mathrm{e} 0+\mathrm{e}_{1} \mathrm{TK}_{i t}+\mathrm{e}_{2} \mathrm{PC}_{i t}$

+ e3IPMit + Uit

Diharapkan bahwa e1, e2, e3 >0

- Pendapatan Disposabel

YDit $=$ PDRBit - TAXit

- Blok Kesejahteraan

- Pengeluaran Per Kapita

PCAPit $=f_{0}+f_{1} Y_{i t}+f_{2} I_{P M}$

$$
+ \text { Uit }
$$

- Distribusi Pendapatan

$\mathrm{GINI}_{\text {it }}=\mathrm{g}_{0}+\mathrm{g}_{1} \mathrm{PDRB}_{\text {it }}+$ $\mathrm{g}_{2} \mathrm{AMH}_{\text {it }}+\mathrm{g}_{3} \mathrm{TK}_{\mathrm{it}}+\mathrm{U}_{\mathrm{it}}$

Diharapkan bahwa g1 >0, g2, g3 <0

- Kemiskinan

\begin{tabular}{|c|c|}
\hline DS & \\
\hline PHEAL & $\begin{aligned}= & \text { Pengeluaran Pemerintah untuk - } \\
& \text { Kesehatan (juta rupiah) }\end{aligned}$ \\
\hline PEDU & $=\begin{array}{l}\text { Pengeluaran Pemerintah untuk } \\
\text { Pendidikan (juta rupiah) }\end{array}$ \\
\hline PM & $=\begin{array}{l}\text { Indeks Pembangunan Manusia } \\
(\%)\end{array}$ \\
\hline HEAL & $=$ Angka Harapan Hidup (tahun) \\
\hline DU & $=$ Pendidikan (tahun) \\
\hline $\mathrm{C}$ & $=$ physical capital riil (juta rupiah) \\
\hline PMTDB & $\begin{aligned}= & \text { Pembentukan Modal Tetap } \\
& \text { Domestik Bruto (juta rupiah) }\end{aligned}$ \\
\hline BM & $=$ Belanja Modal (juta rupiah) \\
\hline DRB & $=\begin{aligned} & \begin{array}{l}\text { Produk Domestik Regional } \\
\text { Bruto (juta rupiah) }\end{array}\end{aligned}$ \\
\hline TK & $=$ Tenaga Kerja (jiwa) \\
\hline YCAP & $=$ PDRB per kapita (juta rupiah) \\
\hline YD & $=\begin{array}{l}\text { Pendapatan disposabel (juta } \\
\text { rupiah) }\end{array}$ \\
\hline PCAP & $=\begin{array}{l}\text { Pengeluaran per kapita (juta } \\
\text { rupiah) }\end{array}$ \\
\hline AMH & $=$ Angka melek huruf $(\%)$ \\
\hline PCAP & $=\begin{array}{l}\text { Pengeluaran per kapita (juta } \\
\text { rupiah) }\end{array}$ \\
\hline POV & $=\begin{aligned} \text { Persentase orang miskin } & \text { dibawah garis kemiskinan }(\%)\end{aligned}$ \\
\hline & Garis Kemiskinan (rupiah) \\
\hline & $=$ Indeks Gini $(\%)$ \\
\hline
\end{tabular}

$\mathrm{POV}_{\text {it }}=\mathrm{h}_{0}+\mathrm{h}_{1} \mathrm{PCAP}_{\text {it }}+$

h2GINIit + h3GMSKNit +Uit

Diharapkan bahwa h1 $<0, h_{2}, h_{3}>0$

Keterangan: 
Tabel 1 Hasil Estimasi menggunakan metode 2SLS

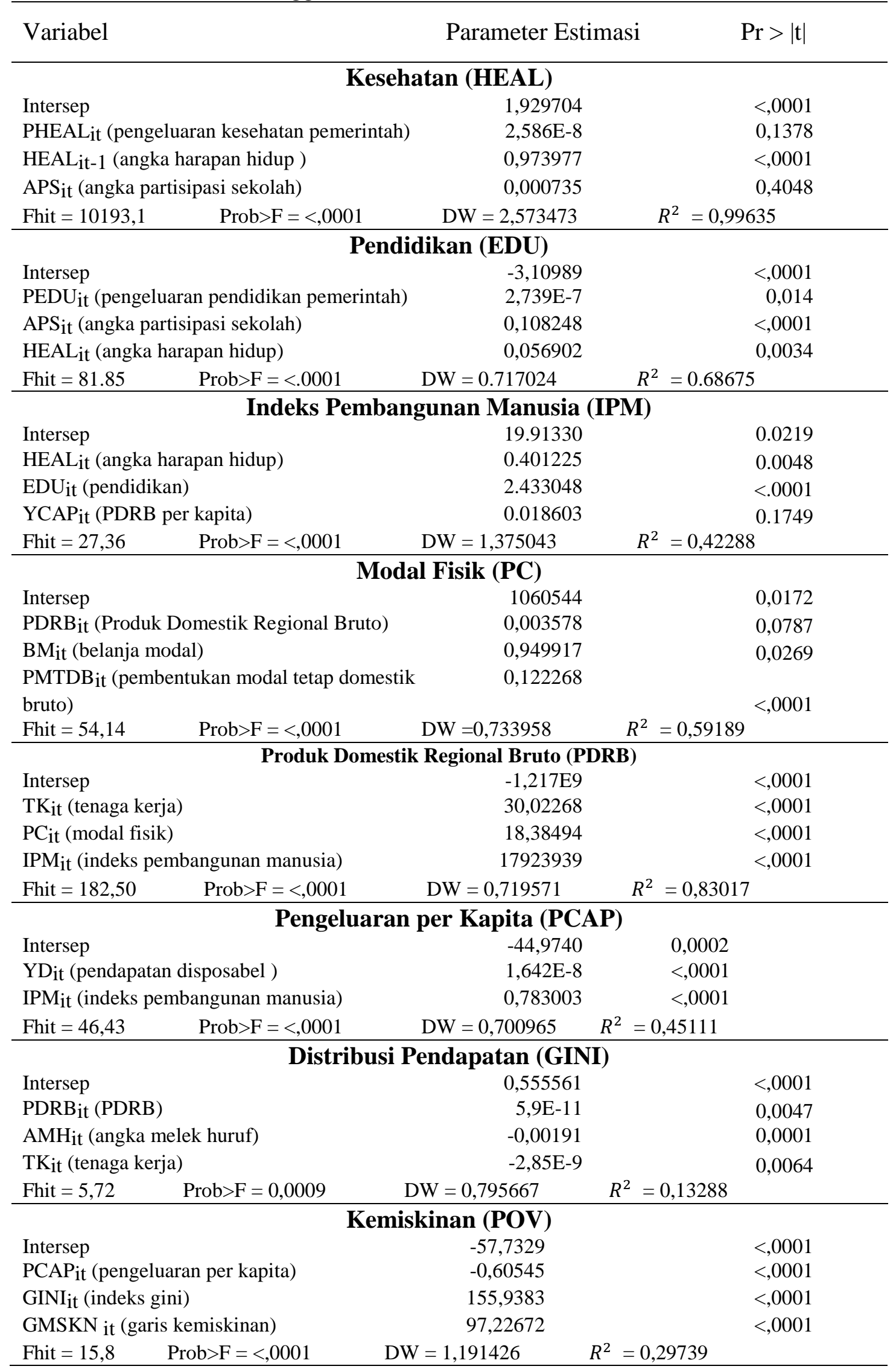




\section{HASIL DAN PEMBAHASAN}

\section{Hasil Estimasi Metode 2SLS}

Secara umum variabel bebas yang ada dalam persamaan mampu menjelaskan dengan baik variabel tak bebasnya. Hal ini terlihat dari pengujian individu yaitu dari 17 peubah penjelas yang dimasukkan dalam model, 15 diantara-nya memiliki pengaruh yang nyata terhadap variable tak bebas pada taraf uji 20\% atau kurang. Oleh karena itu hasil pendugaan model dalam kajian ini dapat digunakan untuk menggambarkan pengaruh pem-bangunan manusia dan belanja modal terhadap kemiskinan.

Pengeluaran bidang kesehatan pemerintah berpengaruh positif dan signifikan dalam meningkatkan kesehatan pada taraf $\alpha=0,13$. Peningkatan kesehatan dan pengeluaran pemerintah untuk sector pendidikan, berpengaruh positif dan signifikan dalam meningkatkan pendidikan masingmasing pada taraf $\alpha=0,01$ dan $\alpha=0,003$. Hasil ini senada dengan penelitian Blankeanu dan Simpson (2004) yang mengatakan bahwa pengeluaran pemerintah untuk pendidikan dan kesehatan berpengaruh langsung dalam meningkatkan human capital dan mendorong terjadinya pertumbuhan ekonomi dalam jangka panjang.

Selain kesehatan yang memiliki pengaruh positif dan signifikan dalam meningkatkan indeks pembangunan manusia pada taraf $\alpha=0.004$, pendidikan juga memiliki pengaruh yang sangat nyata dalam meningkatkan indeks pembangunan manusia. Ini berarti bahwa peningkatan pada kesehatan dan pendidikan, akan menyebabkan peningkatan pada indeks pembangunan manusia.

Peningkatan pada belanja modal dan pembentukan modal tetap domestic bruto (PMTDB) juga berpengaruh nyata terhadap peningkatan modal fisik pada taraf $\alpha=0,02$, dan $\alpha=0,07$. Menurut Yudhoyono (2004) pengeluaran pemerintah yang ditujukan untuk penyediaan infrastruktur (fasilitas publik), selalu berdampak positif bagi pertumbuhan ekonomi. Peningkatan physical capital diharapkan dapat menggerakan perekonomian daerah.

Peningkatan pada physical capital, IPM, serta tenaga kerja juga mempunyai pengaruh sangat nyata dalam meningkatkan PDRB. Hasil ini senada dengan penelitian yang dilakukan oleh Yudhoyono (2004), Sulistyowati (2011) yang menyatakan bahwa investasi sangat penting dalam menggerakan perekonomian, hal ini membutuhkan iklim yang kondusif, yaitu infrastruktur yang memadai, kondisi social politik, keamanan, dan birokrasi yang tidak berbelit.

Selain itu peningkatan indeks pembangunan manusia, PDRB melalui disposable income juga memiliki pengaruh yang sangat nyata dalam meningkatkan pengeluaran per kapita. Hasil ini mendukung penelitian Sulistyowati (2011). Peningkatan indeks pembangunan manusia juga berpengaruh positif dan signifikan dalam meningkatakan pengeluaran per kapita.

Peningkatan pada PDRB juga berpengaruh positif dalam meningkatkan ketimpangan pendapatan pada taraf $\alpha=0,004$. Kondisi yang ada menunjukkan bahwa pertumbuhan ekonomi tidak selalu diikuti oleh pemerataan hasil-hasil pembangunan. Diduga bahwa hasil pembangunan hanya dinikmati oleh sebagian masyarakat khususya golongan orang kaya.

Hasil penelitian ini sejalan dengan penelitian Nanga (2006) bahwa peningkatan PDRB per kapita 
menyebabkan semakin timpangnya distribusi pendapatan masyarakat. Pertumbuhan dan pemerataan mempunyai arah perkembangan yang berbeda-beda. Hubungan antara pendapatan dan pemerataan masih menjadi kontroversi. Banyak ekonom yang masih beranggapan bahwa hubungan antara pertumbuhan ekonomi yang pesat dan distribusi pendapatan adalah saling bertentangan (trade-off).

Selain itu peningkatan pada tenaga kerja dan angka melek huruf memiliki pengaruh negative dan signifikan terhadap ketimpangan pendapatan. Hal ini menunjukkan bahwa pendidikan merupakan salah satu faktor penting dalam mengurangi kemiskinan.

Kesenjangan pembinaan sumberdaya manusia yang terwujud dalam bentuk keterbatasan kesempatan memperoleh pendidikan dan keterampilan merupakan bentukn lain dari ketimpangan distribusi pendapatan atau kepemilikian asset-aset yang berharga dalam masyarakat.

Peningkatan pada ketimpangan pendapatan memiliki pengaruh yang sangat nyata dalam meningkatkan kemiskinan. Hasil penelitian ini sejalan dengan penelitian yang dilakukan oleh Nanga (2006) yang menunjukkan bahwa kemiskinan dengan berbagai ukurannya sensitive terhadap perubahan yang terjadi didalam peubah ketimpangan pendapatan (indeks gini).

Peningkatan pengeluaran per kapita memililiki pengaruh sangat nyata dalam menurunkan tingkat kemiskinan. Hasil penelitian ini sejalan dengan penelitian yang dilakukan oleh Sulistyowati (2011) dan Nanga (2006). Menurut Sulistyowati (2011) adanya peningkatan pengeluaran per kapita yang merupakan indikator pendapatan masyarakat mencerminkan masyarakat semakin sejahtera, yang kemudian pada gilirannya dapat menurunkan tingkat kemiskinan.

Sementara peningkatan garis kemiskinan memililiki pengaruh sangat nyata dalam meningkatkan tingkat kemiskinan. Hasil penelitian ini sejalan dengan penelitian yang dilakukan oleh Sulistyowati (2011) dan Nanga (2006). Peningkatan garis kemiskinan yang tidak disertai dengan peningkatan pendapatan menyebabkan penduduk yang semula hidup di sekitar garis kemiskinan, pendapatan riilnya menjadi menurun, yang menyebabkan meningkatnya kemiskinan (Sulistyowati, 2011).

\section{Hasil Simulasi Dampak Belanja Modal Pemerintah dan Investasi Pembangunan Manusia dalam Mengurangi Kemiskinan di Indonesia}

Sebelum simulasi, dilakukan validasi model untuk mengetahui sejauh mana model yang dibangun akan menghasilkan nilai dugaan yang mendekati nilai sebenarnya (aktual). Hasil validasi berdasarkan U-Theil berada diantara 0,001 sampai dengan 0,28. Begitu pula jika dilihat berdasarkan (UM) dimana nilainya mencapai nol. Dari nilai tersebut mengindikasikan bahwa model ini valid dan dapat digunakan untuk simulasi. 
Tabel 2 Hasil Simulasi Dampak Belanja Modal Pemerintah dan Pembangunan Manusia dalam Mengurangi Kemiskinan di Indonesia

\begin{tabular}{|c|c|c|c|c|c|}
\hline \multirow[b]{2}{*}{ Variabel Endogen } & \multicolumn{5}{|c|}{ Persentase Perubahan } \\
\hline & $\begin{array}{c}\text { Simulasi } \\
1 \\
\end{array}$ & $\begin{array}{l}\text { Simulasi } \\
2 \\
\end{array}$ & $\begin{array}{c}\text { Simulasi } \\
3\end{array}$ & $\begin{array}{c}\text { Simulasi } \\
4\end{array}$ & $\begin{array}{l}\text { Simulasi } \\
5 \\
\end{array}$ \\
\hline $\begin{array}{l}\text { Kesehatan (Angka harapan } \\
\text { hidup) }\end{array}$ & 0,2782 & 0,2816 & 0,2782 & 0,2798 & 0,2791 \\
\hline Pendidikan & 0,3418 & 0,0514 & 0,0502 & 0,1972 & 0,1237 \\
\hline $\begin{array}{l}\text { Indeks Pembangunan } \\
\text { Mannusia }\end{array}$ & 0,2149 & 0,1311 & 0,1294 & 0,1731 & 0,1511 \\
\hline Pengeluaran per kapita & 1,4771 & 0,9255 & 1,3091 & 1,2013 & 1,2552 \\
\hline Modal Fisik & 0,1537 & 0,0644 & 3,4569 & 0,1090 & 1,7830 \\
\hline $\begin{array}{l}\text { Produk Domestik Regional } \\
\text { Bruto }\end{array}$ & 1,6959 & 1,1236 & 2,5413 & 1,4124 & 1,9795 \\
\hline Pendapatan Disposabel & 1,7054 & 1,1281 & 2,5581 & 1,4141 & 1,9861 \\
\hline Indeks GINI & 0,0528 & 0,0264 & 0,0793 & 0,0264 & 0,0528 \\
\hline Kemiskinan & $-0,7914$ & $-0,5888$ & $-0,5997$ & $-0,6901$ & $-0,6449$ \\
\hline
\end{tabular}

Hasil dari simulasi 1, memberi dampak pada peningkatan kesehatan sebesar $0,28 \%$ yang kemudian meningkatkan pendidikan sebesar 0,34\%. Peningkatan pendidikan memberikan dampak pada peningkatan indeks pembangunan manusia sebesar $0,21 \%$ Peningkatan pada kualitas manusia yang di representasikan oleh indeks pembangunan manusia memberikan dampak pada peningkatan PDRB sebesar 1,69\% dan disposable income meningkat sebesar $1,70 \%$. Blankeanu and Simpson (2004) yang mengatakan bahwa pengeluaran pemerintah untuk pendididkan dan kesehatan berpengaruh langsung dalam meningkatkan human capital dan mendorong terjadinya pertumbuhan ekonomi dalam jangka panjang.

Peningkatan output akibat adanya peningkatan pengeluaran untuk pendidikan berpengaruh dalam meningkatkan modal fisik sebesar $0,15 \%$ dan meningkatkan ketimpangan pendapatan sebesar $0,05 \%$ Peningkatan pengeluaran untuk pendidikan membawa dampak positif bagi peningkatan pengeluaran per kapita (sebagai indikator pendapatan masyarakat) sebesar $1,48 \%$ dengan adanya kenaikan pengeluaran per kapita yang lebih besar daripada kenaikan indeks gini, maka hal tersebut dapat menurunkan kemiskinan sebesar $0,79 \%$.

Hasil simulasi 2 peningkatan pengeluaran kesehatan sebesar $20 \%$, memberi dampak pada peningkatan kesehatan sebesar $0,34 \%$, yang kemudian meningkatkan pendidikan sebesar $0,05 \%$. Hasil ini mendukung penelitian Subroto (2013). Kesehatan berperan dalam proses pencapaian pendidikan yang baik. Hasil pendugaan menunjukkan bahwa peningkatan kesehatan berpengaruh positif dan signifikan dalam meningkatkan pendidikan. Modal kesehatan yang baik dapat meningkatkan pengembalian atas pendidikan karena: (1) kesehatan merupakan faktor penting bagi kehadiran di sekolah. (2) anak-anak yang sehat lebih berprestasi di sekolah dan dapat belajar secara lebih efisien, (3) angka kematian anak usia sekolah akan meningkatkan biaya pendidikan per 
tenaga kerja, sementara harapan hidup yang lama akan meningkatkan pengembalian atas investasi pendidikan, dan (4) individu yang sehat akan mampu menggunakan pendidikan secara produktif dalam kehidupannya. Peningkatan pendidikan dan kesehatan memberikan dampak pada peningkatan indeks pembangunan manusia sebesar $0,13 \%$.

Peningkatan pada kualitas manusia yang di representasikan oleh indeks pembangunan manusia memberikan dampak pada peningkatan PDRB sebesar 1,12\% dan disposable income meningkat sebesar $1,13 \%$. Peningkatan output akibat adanya peningkatan pengeluaran untuk kesehatan berpengaruh dalam meningkatkan modal fisik sebesar $0,06 \%$ dan meningkatkan ketimpangan pendapatan sebesar 0,03\%. Peningkatan pengeluaran pemerintah untuk kesehatan membawa dampak positif bagi peningkatan pengeluaran per kapita (sebagai indikator pendapatan masyarakat) sebesar $0,92 \%$, yang kemudian dapat menurunkan kemiskinan sebesar $0,58 \%$.

Hasil perbandingan dengan simulasi 2 yaitu kebijakan peningkatan pengeluaran pemerintah untuk kesehatan, simulasi 1 yaitu kebijakan peningkatan pengeluaran pemerintah untuk pendidikan memberi dampak yang lebih besar dalam menurunkan kemiskinan.

Hasil simulasi 3 peningkatan pengeluaran belanja modal sebesar $20 \%$ memberi dampak pada peningkatan modal fisik sebesar $3,45 \%$ dan meningkatkan ketimpangan pendapatan sebesar $0,07 \%$. Peningkatan pengeluaran belanja modal membawa dampak positif bagi peningkatan pengeluaran per kapita (sebagai indikator pendapatan masyarakat) sebesar $1,31 \%$, yang kemudian dapat menurunkan kemiskinan sebesar 0,59\%. Simulasi 3 mencerminkan kebijakan peningkatan belanja modal pemerintah tanpa adanya peningkatan pada pengeluaran pemerintah pada sector pendidikan dan kesehatan.

Hasil simulasi 4 peningkatan pengeluaran pemerintah untuk sektor pendidikan dan kesehatan masingmasing sebesar 10\%, memberi dampak pada peningkatan kesehatan dan pendidikan masing-masing sebesar $0,28 \%$ dan $0,2 \%$. Peningkatan pendidikan dan kesehatan memberikan dampak pada peningkat-an indeks pembangunan manusia sebesar $0,17 \%$.

Peningkatan pada kualitas manusia yang di representasikan oleh indeks pembangunan manusia memberikan dampak pada peningkatan PDRB sebesar $1,42 \%$ dan disposable income meningkat sebesar $1,41 \%$. Peningkatan output akibat adanya peningkatan pengeluaran untuk kesehatan berpengaruh dalam meningkatkan modal fisik sebesar $0,11 \%$ dan meningkatkan ketimpangan pen-dapatan sebesar $0,02 \%$. Peningkatan pengeluaran pemerintah untuk sektor pendidikan dan kesehatan membawa dampak positif bagi peningkatan pengeluaran per kapita (sebagai indikator pendapatan masyarakat) sebesar $1,2 \%$, yang kemudian dapat menurunkan kemiskinan sebesar $0,69 \%$.

Bila dibandingkan dengan simulasi 3 yaitu kebijakan peningkatan belanja modal, kebijakan peningkatan pengeluaran pendidikan dan kesehatan (simulasi 4), memberi dampak yang lebih besar dalam 
menurunkan kemiskinan. Namun dampak pengurangan kemiskinannya masih lebih rendah dari simulasi 1 .

Hasil simulasi 5 peningkatan pengeluaran pemerintah untuk sector pendidikan sebesar $10 \%$ dan pengeluaran pemerintah sector kesehatan serta belanja modal masing-masing sebesar 5\%, memberi dampak pada peningkatan kesehatan dan pendidikan masing-masing sebesar $\quad 0,27 \%$ dan $0,12 \%$. Peningkatan pendidikan dan kesehatan memberikan dampak pada peningkatan indeks pembangunan manusia sebesar $0,12 \%$.

Peningkatan pada kualitas manusia yang di representasikan oleh indeks pembangunan manusia memberikan dampak pada peningkatan PDRB sebesar 1,97\% dan disposable income meningkat sebesar $1,98 \%$. Peningkatan output akibat adanya peningkatan pengeluaran untuk kesehatan berpengaruh dalam meningkatkan modal fisik sebesar $1,78 \%$ dan meningkatkan ketimpangan pendapatan sebesar 0,05\% Peningkatan pengeluaran pemerintah untuk pendidikan, kesehatan, dan belanja modal membawa dampak positif bagi peningkatan pengeluaran per kapita (sebagai indikator pendapatan masyarakat) sebesar $1,25 \%$, yang kemudian dapat menurunkan kemiskinan sebesar $0,64 \%$.

Hasil perbandingan antara simulasi 2, 3, dan 4. Simulasi 5 memberikan dampak pengurangan kemiskinan yang lebih besar, Namun pengurangan kemiskinannya masih lebih rendah apabila dibandingkan dengan simulasi 1 yaitu dampak kebijakan pengeluaran pemerintah untuk pendidikan.

\section{KESIMPULAN DAN SARAN}

\section{Kesimpulan}

Skenario simulasi dengan persentase yang sama, kebijakan peningkatan pengeluaran kesehatan memberikan hasil yang paling baik dalam peningkatan kesehatan, pendidikan, indeks pembangunan manusia, pengeluaran per kapita, PDRB, disposable income, dan pengurangan kemiskinan. Sedangkan kebijakan peningkatan belanja modal pemerintah memberikan hasil yang paling baik dalam peningkatan physical capital. Sementara kebijakan peningkatan pengeluaran pendidikan dan kesehatan lebih banyak memberi dampak positif dalam pengurangan kemiskinan. Skenario gabungan peningkatan pengeluaran pendidikan dan kesehatan yang disertai peningkatan belanja modal pemerintah memberi dampak yang paling besar dalam mengurangi tingkat kemiskinan di Indonesia.

\section{Saran}

\section{Strategi pembangunan yang} tidak hanya mengedepankan pembangunan fisik, namun juga mengedepankan peningkatan kualitas sumberdaya manusia sebaiknya dijadikan sebagai salah satu strategi pembangunan daerah di Indonesia, karena dampaknya dapat lebih besar dalam menurunkan kemiskinan. Mengingat peran penting pendidikan dalam meningkatkan kualitas SDM, sebaiknya pemerintah menlakukan pembenahan terhadap sistem pendidikan di Indonesia, agar dampaknya terhadap pembangunan dapat lebih optimal. Apabila pemerintah akan menurunkan tingkat kemiskinan dan meningkatkan pendapatan masyarakat maka 
sebaiknya kebijakan yang diambil adalah meningkatkan pengeluaran untuk sektor kesehatan.

\section{DAFTAR PUSTAKA}

Balisacan AM, Pernia EM, Asra A. 2003. Revisiting Growth and Poverty Reduction in Indonesia : What Do Subnational Data Show? . Bulletin of Indonesian Economic Studies, 39(3) : 329351.

Blankeanu WF, Simpson NB. 2004. Public Education Expenditures and Growth. Journal of Development Economcs, 73: 583-605.

Bidani B. dan Ravallion M. 1993. A Regional Poverty Profile for Indonesia. Bulletin of Indonesia and Economic Studies, 29 (3) : 37- 68.

Brata G. 2005. Investasi Sektor Publik Lokal, Pembangunan Manusia, dan Kemiskinan. Lembaga Penelitian Universitas Atma Jaya Yogyakarta, Februari

Chemingui, Abdelbasset M. 2007. Public Spending and Poverty Reduction in an Oil based Economy: The Case of Yemen. Revised: January

Dagdeviren H, Hoeven R, Weeks J. 2002. Redistribution Does Matter: Growth and Redistribution for Poverty Reduction. WIDER Discussion Paper, No. 2002/05.

Eigbiremolen, Anaduaka. 2014. Human Capital Development and Economic Growth: The Nigeria Experience. International Journal of Academic Research in Business and Social Sciences. 4(4):12-14.
Fan S. 2000. How Does Public Spending Affect Growth and Poverty? The Experience of China. Paper submitted to 2nd annual Global Development Network Confrence. Tokyo, Japan.

Fane G, Warr P. 2002. How Economic Growth Reduces Poverty : A General Equilibrium Analysis for Indonesia. Discussion Paper No. 2002/9. United Nations University/ WIDER.

Gomanee, Karuna. 2003. Aid, Public Spending and Human Welfare: Evidence From Quantile Regressions, Paper for a Session on 'Poverty and Human Development. Glasgow. 10-12 September

Hudaya, D. 2009. Faktor-faktor yang mempengaruhi tingkat kemiskinan di Indonesia. [skripsi]. Bogor (ID). Fakultas Ekonomi, Institut Pertanian Bogor.

Nanga M. 2006. Dampak Transfer Fiskal terhadap Kemiskinan di Indonesia: Suatu Analisis Simulasi Kebijakan. Disertasi Doktor. Sekolah Pascasarjana, Institut Pertanian Bogor, Bogor.

Putri SM. Yuliarmi NN. 2013. Beberapa Faktor yang Memengaruhi Tingkat Kemiskinan di Provinsi Bali. E-Jurnal EP Unud, 2(10):441448

Saputra WA. 2011. Analisis pengaruh jumlah penduduk, PDRB, IPM, pengangguran terhadap tingkat kemiskinan di kabupaten/kota Jawa Tengah. [skripsi]. Semarang (ID): Fakultas Ekonomi, Universitas Diponegoro.] 
Sang Jung H dan Thorbecke E. 2001.

The Impact of Public

Education Expenditure on

Human Capital, Growth, and Poverty in Tanzania and Zambia A General Equilibrium Approach. IMF Workng Paper 1(106):1-36

Subroto G. (2013). Peran Pendidikan Dalam Pertumbuhan Ekonomi Sektoral di Indonesia. Disertasi Doktor. Sekolah Pascasarjana, Institut Pertanian Bogor, Bogor.

Sulistyowati N. 2011. Dampak Investasi Sumber daya Manusia Terhadap Perekonomian dan Kesejahteraan Masyarakat di Jawa Tengah. Disertasi. Institut Pertanian Bogor: Sekolah Pascasarjana, Bogor.

Sumargo B, Yuniarty T. 2009. Model Persamaan Struktural Pembangunan Manusia dalam Kaitannya dengan Investasi Sektor Fisik, Manusia, Pendidikan, dan Kesehatan di Indonesia. Jurnal Mat Stat 9(2):108-117.

Sumarsono S. 2009. Teori dan Kebijakan Publik Ekonomi
Sumber Daya Manusia. Yogyakarta (ID): Graha Ilmu. Todaro MP, Smith SC. 2003. Pembangunan Ekonomi di Dunia Ketiga. Jakarta (ID): Erlangga.

Widodo A, Waridin, Maria J. 2011. Analisis Pengaruh Pengeluaran Pemerintah di Sektor Pendidikan dan Kesehatan Terhadap Pengentasan Kemiskinan Melalui Peningkatan Pembangunan Manusia di Provinsi Jawa Tengah. Jurnal Dinamika Ekonomi Pembangunan 1(1):25-42

Wiguna VI. 2013. Analisis Pengaruh PDRB, Pendidikan, Pengangguran terhadap $\mathrm{Ke}$ miskinan di Provinsi Jawa Tengah Tahun 2005-2010. Jurnal Ilmiah Mahasiswa FEB $U B$.

Yudhoyono SB. 2014. Pembangunan Pertanian dan Pedesaan Sebagai Upaya Mengatasi Kemiskinan dan Pengangguran: Analisa Ekonomi Politik dan Kebijakan Fiskal. [disertasi]. Semarang (ID): Fakultas Ekonomi, Institut Pertanian Bogor. 